\title{
Effects of Composting on Growth and Uptake of Plant Nutrients and Soil Chemical Properties After Composting with Various Comparison of POME
}

\author{
Erwanda Surya*1, Hamidah Hanum ${ }^{1}$, Chairaini Hanum ${ }^{1}$, Abdul Rauf ${ }^{1}$, Benny \\ Hidayat $^{1}$, Fitra Syawal Harahap ${ }^{2}$.
}

\author{
${ }^{1}$ Magister Study Agrotechnology Program Faculty of Agriculture Universitas Sumatera Utara, Indonesia \\ ${ }^{2}$ Agrotechnology Study Program Faculty of Sainsand Teknologi UniversitasLabuhanbatu, Indonesia \\ *Email : erwandas@gmail.com
}

\begin{abstract}
Effects of Composting on Growth and Uptake of Plant Nutrients and Soil Chemical Properties After Composting with Various Comparison of POME aims to find out the provision of compost with various comparisons of POME in improving soil chemical properties and to know the treatment of compost types with various comparisons of POME to Plant Nutrient Growth and Uptake research this will be carried out in the Research will be carried out in the Bangun Bandar PT. Socfindo, Serdang Bedagai district, Dolok Masihul sub-district with a height of $\pm 25 \mathrm{~m}$ above sea level. The research will be carried out in January - August 2018. As for the method used The mixture of soil and compost samples that have been incubated for 1 month is taken from each sample as much as $1 \mathrm{~kg}$ and analyzed the nutrients in the laboratory by the wet decstructive method pH H2O 1: 2.5 , N-Total (Kjeldahl destilation), C-Organic (Walky and Black titration), P-Bray II (spectrophometer) and CEC (Ammonium acetate pH 7). Plant Height (cm), Plant Bump Diameter (cm), Weight Measurement, Wet and Dry Weights, Weights, Dry Roots, Nisbah, Roots Results of the study Compost giving with various comparisons of POME 1: 1.3, 1: 1.9 and 1: 2.6 improves the soil chemical properties: total $N$ incubated for 1 month. The compost treatment with various POME 1: 2.6 comparisons gave the highest results. The compost treatment with various POME comparisons significantly affected plant height, plant tuber diameter, canopy wet weight, canopy dry weight and root canopy ratio, leaf $P$ nutrient content, Ca levels leaf and plant nutrient uptake $(N, P, K, C a, M g)$. In general the treatment of compost with various POME 1: 1.9 comparisons showed the highest results.
\end{abstract}

Keywords-Composting, Soil Chemical Properties, Plant Nutrient Uptake, Comparison of POME

\section{INTRODUCTION}

The emergence of palm oil mills accompanied by the results of waste in the form of solids and large amounts of liquid [7]. Liquid waste from palm oil mills still has the potential as environmental pollution because it smells, has color, contains COD, BOD values and high suspended solids. If the waste is discharged directly into the environment, then some will settle, decompose slowly, consume dissolved oxygen, cause turbidity, emit a sharp odor and can damage the environmental ecosystem [3]. Waste produced by oil palm plants can provide great benefits for life, including as organic fertilizer and as charcoal. Utilization of these wastes is processed into compost. Composting is one way to increase nutrient value and reduce the volume of oil palm empty fruit bunches, the most widely used method is aerobic composting because it is cheap and easy to do and does not require too difficult process control. While composting anaerobicly utilizes microorganisms that do not need air in degrading organic material [5]

Palm oil mill waste management is by utilizing the waste to be processed into compost with a bunker system (aerated bunker composting system), because this system can reduce methane gas emissions. In the process of making compost, it is expected that all waste will be used up (zero waste), but in reality until now only all of the liquid waste has not been used (still $+50 \%$ of the total liquid waste generated from the factory). have been us ing GIS mapping of actual and potential land suitability for oil palm[11].

The results showed that with the addition of PKS liquid waste, the average temperature of the TKS heap was 
higher, the nutrient content of the compost formed had increased. Only the disadvantage with aerobic composting produced unpleasant odors in the first and second weeks of composting, in the treatment given urea the foul odor occurred until the 5th week. However, if liquid waste is given in fresh form, then no rotting odor is formed [10]. According to [5] compost from oil palm bunches has been made simply by adding palm oil mill wastewater.

The results of this composting contain $3.45 \%$ potassium, $0.022 \%$ phosphorus, organic carbon (C) $29.76 \%$ and $54.39 \%$ water content. Showed that the composting method used the Bunker system, the ratio between the yield of empty bunches to POME was 1: 5 producing compost with the highest nutrient / nutrient content of Nitrogen, Phosphorus and Potassium over a period of 25 days [14]. The treatment of compost significantly affected plant height, plant tuber diameter, canopy wet weight, canopy dry weight and root canopy ratio was $25 \%$ POME [15]..

Utilization of compost in the main nurseries is one of the most important materials applied in the nursery media. From the results of experiments on the main nurseries of oil palm showed that the application of compost in planting media, can increase plant height and the number of midribs on oil palm seedlings [4]. According to [13], that compost can increase soil CEC from 4 to $6 \mathrm{cmol} / \mathrm{kg}$ and also soil $\mathrm{pH}$. Fertilization of oil palm seeds can be done by adding inorganic and organic fertilizers [2].

\section{MATERIALS AND METHODS}

\section{Place and time of research}

The research will be carried out in the Bangun Bandar PT. Socfindo, Serdang Bedagai district, Dolok Masihul sub- district with altitude $\pm 25 \mathrm{~m}$ above sea level. The research will be conducted in January - August 2018

\section{Materials and methods}

This study uses oil palm seedlings from DxP Deli Lame variety from PT. Socfindo who is 3 months old after the seedlings. The materials used include: NPK 15-15-6-4 (nutrient content was analyzed using the wet decstructive method), top soil (ultisol), oil palm empty fruit bunches that have been "pressed", solid ex-decanter, ashes cyclon boiler dust, liquid waste from fat pit (POME - Palm Oil Mill Effluent), fungicides with active ingredients mankozeb and insecticides. The tools used in this study are bunker buildings, polybags measuring $42.5 \mathrm{~cm} \mathrm{x} 50 \mathrm{~cm} \mathrm{x}$ $0.2 \mathrm{~mm}$, wire sieves, wooden boxes measuring $1.5 \mathrm{mx} 1.5$ $\mathrm{mx} 0.6 \mathrm{~m}$, hoes, tools ground drill, scales, ZE 30D sprinkles, gauges (roll, calipers), ovens, and stationery.

\subsection{Parameters Observed}

Soil Chemical Characteristics Soil mixtures and compost samples that have been incubated for 1 month are taken from each treatment as much as $1 \mathrm{~kg}$ and analyzed for nutrients in the laboratory with wet $\mathrm{H} 2 \mathrm{O}$ 1: 2.5, N-Total (Kjeldahldestilation), C- Organic (Walky and Black titration), P-Bray II (spectrophometer) and CEC (Ammonium acetate $\mathrm{pH} 7$ ). Plant Height (cm), Diameter of Crop Bump (cm), Measurement of Weights, Wet and Dry .Weights, Weights, Dry Roots, Nisbah, Rootbill

\section{RESULTS AND DISCUSSION}

3.1.Chemical Properties of Soil After Composting with Various Comparison of POME

Changes in soil chemical properties: $\mathrm{pH}, \mathrm{C}$ organic, total $\mathrm{N}, \mathrm{C}$-organic, P-Bray II and $\mathrm{CEC}$ in the provision of compost with various comparisons can be seen in Table 1.

Table 1. Chemical Properties of Soil 1 month after Incubation Type of Compost with Various Comparison of POME

\begin{tabular}{cccccc}
\hline $\begin{array}{c}\text { Compost Treatment } \\
\text { (TKKS: POME) }\end{array}$ & pH-H ${ }_{2} \mathrm{O}$ & C-Org. & N total & P-Bray II & KTK \\
\hline \multirow{3}{*}{ Control } & & $\%$ & $\%$ & $\mathrm{mg} / \mathrm{kg}$ & $\mathrm{cmol} / \mathrm{kg}$ \\
& 6.79 & 1.22 & 0.25 & 635.68 & 12.41 \\
$1: 0.6$ & Very high & Low & High & Very high & Low \\
& 6.56 & 1.55 & 0.25 & 871.59 & 13.22 \\
$1: 1.3$ & Very high & Low & High & Very high & Low \\
& 6.33 & 2.08 & 0.26 & 629.19 & 13.13 \\
$1: 1.9$ & Very high & Low & Very high & Very high & Low \\
& 7.03 & 1.46 & 0.27 & 684.38 & 14.81 \\
$1: 2.6$ & Very high & Low & Very high & Very high & Low \\
& 7.02 & 1.36 & 0.40 & 640.13 & 12.79 \\
\hline
\end{tabular}

Description: Criteria for assessment of soil chemical properties according to Fairhurst and Hardter (2010). 
From Table 1 above shows that the treatment of compost with various comparisons of POME did not change the status of the chemical properties of $\mathrm{pH}, \mathrm{P}$-Bray II and soil CEC. However, it showed a change in nutrient status of C-organic in the type treatment with various POME 1: 1.3

\subsection{Effects of Composting with Various POME Comparisons on Plant Nutrient Growth and Uptake}

Based on the results of variance shows that compost treatment with various

comparisons of POME has a very significant effect on plant height, tuber diameter, canopy wet weight, canopy dry weight and has a significant effect on root canopy ratio, but does not significantly affect root wet weight and seed root dry weight Palm oil. Growth of oil palm seedlings in compost treatment with various POME comparisons can be seen in Table 2.From Table 2 above it can be seen that all compost treatments with various comparisons of POME 1: $0.6,1: 1.3,1: 1.9,1$ : 2.6give a better response than the control of increasing plant height, comparisons compared to other treatments that was $2.08 \%$. Likewise, the change in the total $\mathrm{N}$ status (very high criteria) in compost type treatment with various comparisons of POME 1: 1.3, 1: 1.9 and 1: 2.6 where the higher the POME ratio the higher the total $\mathrm{N}$ content.

tuber diameter, canopy wet weight, weight dry crown and root canopy ratio. The compost treatment with various POME 1: 1.9 comparisons gave the highest yields to the growth of oil palm seedlings.

\subsection{Discussions}

The treatment of compost with various POME comparisons did not significantly affect the chemical properties of the soil, namely $\mathrm{pH}$, organic $\mathrm{C}$, total $\mathrm{N}$, available $\mathrm{P}$ and CEC. It is suspected that in this study, the seedling planting media used were previously mixed with rock phosphate fertilizer as a base fertilizer of $75 \mathrm{~g} / 20 \mathrm{~kg}$ of soil, which can be seen that the $\mathrm{pH}$, total $\mathrm{N}$ and $\mathrm{P}-$ content were available with the criteria: high-very high in the treatment control (Table 1).

Table 2. Growth of Oil Palm Seedlings by Providing Compost Types with Various Comparison of POME

\begin{tabular}{|c|c|c|c|c|c|c|c|}
\hline \multirow{2}{*}{$\begin{array}{l}\text { Note: } \\
\\
\\
\text { Treatment } \\
\text { (TKKS: } \\
\text { POME) }\end{array}$} & \multicolumn{7}{|c|}{ Pertumbuhan } \\
\hline & $\begin{array}{l}\text { High } \\
\text { Plant }\end{array}$ & $\begin{array}{c}\text { Diameter } \\
\text { Cob }\end{array}$ & $\begin{array}{c}\text { Weight } \\
\text { Wet } \\
\text { Header }\end{array}$ & $\begin{array}{c}\text { Weight } \\
\text { Wet Root }\end{array}$ & $\begin{array}{c}\text { Weight } \\
\text { Dry } \\
\text { Heading }\end{array}$ & $\begin{array}{c}\text { Weight } \\
\text { Dry } \\
\text { Root }\end{array}$ & $\begin{array}{c}\text { Ratio } \\
\text { Heading } \\
\text { Root }\end{array}$ \\
\hline & $\mathrm{Cm}$ & $\mathrm{cm}$ & $\mathrm{G}$ & $\mathrm{g}$ & $\mathrm{g}$ & $\mathrm{g}$ & \\
\hline Kontrol & $83.48 b$ & $4,19 \mathrm{~d}$ & $310.53 \mathrm{c}$ & 118.33 & $63.69 \mathrm{c}$ & 35.34 & $1.81 \mathrm{~d}$ \\
\hline $1: 0.6$ & $91.17 \mathrm{a}$ & 4.79ab & $439.00 \mathrm{ab}$ & 128.60 & $95.27 \mathrm{ab}$ & 39.35 & $2.54 \mathrm{ab}$ \\
\hline $1: 1.3$ & $89.60 \mathrm{a}$ & $4.64 b c$ & $390.67 b$ & 114.80 & $84.33 b$ & 36.00 & $2.33 b c$ \\
\hline $1: 1.9$ & $93.40 \mathrm{a}$ & $5.09 \mathrm{a}$ & $500.13 \mathrm{a}$ & 137.60 & $105.67 \mathrm{a}$ & 41.64 & $2.53 \mathrm{ab}$ \\
\hline $1: 2.6$ & $91.85 \mathrm{a}$ & $4.87 \mathrm{ab}$ & $452.53 \mathrm{ab}$ & 128.40 & $105.51 \mathrm{a}$ & 39.43 & $2.72 \mathrm{a}$ \\
\hline
\end{tabular}

The

numbers on the line followed by the same letters show no significant difference with the DuncanMultipe Range Test (DMRT) at the $\alpha$ level of $5 \%$

The results of the study by explain that the application of oil palm empty fruit bunches compost and various doses of compound fertilizer in soil mixture with OPEFB compost incubated for 14 days has no significant effect on $\mathrm{pH}, \mathrm{C}$-organic, $\mathrm{N}$-total and $\mathrm{Mg}$. But statistically, the treatment of compost with various comparisons of POME 1: 1.3, 1: 1.9 and 1: 2.6 can increase the total $\mathrm{N}$ content of the soil with very high criteria, the more volume of POME given in the composting process the more the total $\mathrm{N}$ content increases. This is in line with the results of compost quality enriched by various POME comparisons, where the more volume of POME used the higher the nutrient content of C-organic, N, P, K and Mg. [15] The treatment of NPK fertilizer dosage has a very significant effect on plant tuber diameter, canopy wet weight and canopy dry weight that is $25-50 \%$ the NPK fertilizer dose. and According to POME is rich in organic compounds and carbon dioxide. POME contains large amounts of nitrogen, phosphate, calcium, magnesium, and potassium so that it can be used as fertilizer[6].

The treatment of compost enriched with various comparisons of POME 1: 0.6, 1: 1.3, 1: 1.9, 1: 2.6 has a very significant effect and gives the same response to leaf $\mathrm{P}$ levels compared to control. This shows that the provision of compost to the planting medium can increase nutrient absorption which is transplanted to the plant canopy. The results of the study of [12], the treatment of compost application of empty fruit bunches in planting media in the main seedlings of oil palm plants showed a very significant effect on leaf $\mathrm{P}$ nutrient content, leaf $\mathrm{K}$, height and diameter of plant tuber. According to [13] the provision of POME is able to increase the CEC so that the 
$\mathrm{P}$ derived from fertilizers and $\mathrm{P}$ which are not available can become available. [9] states that phosphorus is an essential macro nutrient that plays an important role in various processes, such as photosynthesis, assimilation and respiration. According to [16] and [1] phosphorus is a structural component of a number of energy transfer molecules, ADP, ATP, NAD, NADH, as well as DNA and RNA genetic information system compounds. Phosphate is needed by plants for cell formation in the growing root and shoot tissues and to strengthen the stem, so it does not easily collapse in natural ecosystems.

\section{CONCLUSION}

1. Giving compost with various comparisons of POME 1: 1.3, 1: 1.9 and 1: 2.6 improves the chemical properties of the soil: the total $\mathrm{N}$ incubated for 1 month. Compost treatment with various POME 1: 2.6 comparisons gives the highest results.

2. The treatment of compost with various comparisons of POME significantly affected plant height, plant tuber diameter, canopy wet weight, canopy dry weight and root canopy ratio, leaf $\mathrm{P}$ nutrient content, leaf $\mathrm{Ca}$ content and plant nutrient uptake $(\mathrm{N}, \mathrm{P}, \mathrm{K}$, $\mathrm{Ca}, \mathrm{Mg}$ ). In general the treatment of compost with various POME 1: 1.9 comparisons showed the highest results.

\section{REFERENCES}

[1]. Aleel, K.G. 2008. Phosphate Accumulation in Plant: Signaling. Plant Physiol. 148:3-5.

[2]. Andoko, A. 2005. Budidaya Tanaman Dengan Pupuk Hayati. Penebar Swadaya. Jakarta.

[3]. Betty, J.S., 1996, "Penanganan Limbah Industri Pangan", Kanisius, Yogyakarta.

[4]. Darmosarkoro, W, Edy, S.S, dan Winarna. 2010. Lahan dan Pemupukan Kelapa Sawit, Edisi 1. Pusat Penelitian Kelapa Sawit.

[5]. Darnoko dan Ady S. S. Pabrik Kompos di Pabrik Sawit. Tabloid Sinar Tani, 9 Agustus 2006.

[6]. Deublein, D, Steinhauster A. 2008. Biogas from Waste and Renwable Resources. Winley-VCH Verlag $\mathrm{GmbH} \& \mathrm{Co}$. KGaA. Wetnhetm.

[7]. Fauzi, Yan Ir. 2002. KelapaSawit, Budidaya, Pemanfaatan Hasil dan Limbah Analisa, Usaha dan Pemasaran. EdisiRevisi. Jakarta: PenebarSwadaya.

[8]. Fairhurst, T.H. and Hardter, R. 2010. Oil Palm. Management For Large and Sustainable Yields. International Plant Nutrition Institute.

[9]. Gardner, F.P., R.B. Pearce, dan R.L. Mitchell, 1985. Physiology of Crop Plants. The Iowa State University Press, Anes, Iowa. 50010.

[10]. Hanafiah, K.A, 2005. Dasar-Dasar Ilmu Tanah. Jakarta : PT. RajaGrafindoPersada.
[11]. Harahap FS, Sitompul R, Rauf A, Rahmawaty, Harahap DE, Walida H. 2019. Land suitability evaluation for oil palm plantations ( Elaeis guineensis Jacq.) on Sitellu Tali Urang Julu, Pakpak Bharat District. IOP Conf. Ser.Earth Environ. Sci. 260:012116. DOI: 10.1088/1755 -1315/260/1/012116.

[12]. Hanum, H, Lisnawita, Tantawi, A.R. 2015. The Increasing of N, P, and K Nutrient in Palm Oil Under Prenursery Seedling By Application of Palm Oil Waste Compost and Endofitic Microbes. In conjunction with The 8th International Conference of Chemical Engineering on Sci. and App. (ChESA) 2015 September 9-11, Banda [1]. Aceh, Indonesia.

[13]. Kusumastuti A. 2014. Dinamika P tersedia, pH, C-Organik dan serapan P Nilam (PogostemoncablinBenth.) pada berbagaiarasbahanorganik dan Fosfat di Ultisols. JurnalPenelitianPertanianTerapan. 14 (3): 145-151.

[13]. Rahman, G., A. 2009. Impact of Compost on Soil Properties and Crop Productivity In the Sahel North Burkina Faso. American-Eurasian J. Agric. \& Environ. Sci., 6 (2): 220-226.

[14]. Silalahi, B. M. dan Supijatno. 2017.Pengelolaan Limbah Kelapa Sawit (Elaeis guineensisJacq.) di Angsana Estate, Kalimantan Selatan.Bul. Agrohorti 5(3) : 373 - 383.

[15]. Surya, E., Hanum, H., Hanum, C., dan Harahap, F. S. 2019. Pengaruh pemberian kompos bunker diperkaya dengan limbah cair pabrik kelapa sawit pada pertumbuhan bibit kelapa sawit di bibitan utama. Jurnal Tanah dan Sumberdaya Lahan, 6(2), 1281-1289.

[16]. Thompson, L.M. and F.R. Troeh. 1978. Soil and Fertility. New York, Mc Graw-Hill Book Company. 368 p. 